\title{
Ship engines and air pollutants: emission during fuel change-over and dispersion over coastal areas
}

\author{
Giuseppe Langella $^{1} \cdot$ Paolo Iodice $^{1} \cdot$ Amedeo Amoresano $^{1} \cdot$ Adolfo Senatore $^{1}$
}

Received: 25 February 2016/Accepted: 6 June 2016/Published online: 16 June 2016

(c) The Author(s) 2016. This article is published with open access at Springerlink.com

\begin{abstract}
The emission of air pollutants from ships of large size is a key factor in air quality state in the surrounding areas to ports. The work proposes a methodology for assessing the environmental impact of maritime traffic on air quality of port areas, evaluating the production and the dispersion of air pollutants produced by marine engines of large size during the approach phase to the port. According to current regulations, different scenarios have been analyzed, taking into account the possibility of fuel changeover, from heavy fuel oil (HFO) to marine gas oil (MGO), approaching the port. Emissions during the switch from HFO to MGO have been characterized. The analysis takes into account the most frequent routes of ships moving towards and away from the port. Different scenarios of pollutant emission from ships arriving and departing have been considered, evaluating in particular the effect on the coastal zone adjacent to the port. The results are represented graphically and provide valuable insights into the impact of marine traffic on air quality. Such information may be seen as useful tools for the improvement of maritime legislation on emissions.
\end{abstract}

Keywords Marine diesel engines - Air pollutant emission and dispersion $\cdot$ Fuel change-over

Giuseppe Langella

giulange@unina.it

1 Dipartimento di Ingegneria Industriale, Università degli Studi di Napoli Federico II, Via Claudio 21, 80125 Naples, Italy

\section{Introduction}

Maritime transport is a vital sector for the global economy since over $80 \%$ of freight is transported by ships [1]. That is also the most energy efficient and sustainable mode of transportation of goods from an environmental perspective, whereas $\mathrm{CO}_{2}$ emissions required to carry a ton of freight per kilometer by sea are just $25 \%$ of those on road transport for the same distance, and only $1 \%$ of those provided by the air transport.

The air pollution caused by maritime traffic represents today a key factor in air quality. Ports, in particular, represent certainly a concentrated area of marine transport, significantly affecting environmental quality and human health in the neighboring areas [2].

Emissions from marine traffic and dispersed in coastal areas are growing in recent years in part because of widespread actions worldwide aimed to reduce emissions deriving from road transport sector during the last years [3]. Recent evaluations of total sulfur and nitrogen oxide emissions from worldwide marine traffic report $6.49 \mathrm{Tg} \mathrm{S}$ and $6.87 \mathrm{Tg} \mathrm{N}$, respectively [4]. Emission containing nitrogen oxides $\left(\mathrm{NO}_{x}\right)$ and sulfur ones $\left(\mathrm{SO}_{x}\right)$ are transformed into secondary pollutants, such as ozone and PM, through physical and chemical reactions that occur in the atmosphere. Despite current emissions from shipping constitute a small part of total emissions, they may nevertheless represent a significant rate in the coastal areas near the ports, as shown in numerous studies and data collections performed worldwide [5-10].

According to the data of the International Maritime Organization, $80 \%$ of maritime traffic takes place in the northern hemisphere and most of this affects marine areas within a few hundred kilometers from the coast. Within these areas, weather conditions play a key role in the 
dispersion of pollutants on the coast. However, in recent decades the international environmental regulation focused more on land-based sources than on maritime ones. In this sense, marine sources of air pollution, though growing, are still less regulated than terrestrial ones. Moreover, the marine traffic is expected to grow in the coming decades and with it air pollution and its impact on coastal regions [11]. For this reason, it is increasingly important to correctly evaluate the influence of naval transports on air quality of coastal areas.

While scientific literature has been enriched in recent years by many publications on exhaust gas composition of marine engines [12-14], the number of studies evaluating the impact of shipping emissions on air quality is not sufficient above all regarding the fuel change-over. Some works dealing with shipping emission estimations are based on chemical and dispersion transport models and on emission inventories, in addition to on board emissions [15], with the aim to characterize and quantify the impact of the maritime transport sector on air quality degradation; however, most of these studies focus on climate impacts of shipping emissions [16-19], while studies dealing with effects on urban air quality over coastal areas are rather limited. Besides, it must be emphasized that these results were obtained using different approaches and calculation procedures in the different regions, since no common EUwide methodology is now available. Therefore, a more homogeneous application of modeling approaches could be the only possibility to move towards comparable data on the impact of shipping emissions on urban air quality. Likewise, the application of similar methods across different regions could improve comparability between results [20]. Besides, to plan and implement effective regulation to minimize environmental effects of these emissions, comprehensive knowledge of their impacts on climate and of their influence to atmospheric pollution is required.

This study responds precisely to this need by proposing a methodology for assessing the environmental impact of maritime traffic on air quality of port areas. In particular, the study covers emissions from large size two-stroke diesel engines, taking into account the fuel change-over from heavy fuel oil (HFO) to marine gas oil (MGO) and vice versa, moving toward and away from the port.

The methodology proposed in this study proves to be a useful and standardized tool to investigate both the impact of the air pollutants from ship engines during fuel changeover on the ambient air quality levels along coastal areas and how the foreseen future evolution of ship traffic and the geographical expansion of ports are going to affect the atmospheric composition.

More specifically, the objective of this study is to propose a calculation procedure for assessing and quantifying numerically the environmental impact of maritime traffic on air quality of port areas during the approach phase of the ships. Using this methodology, it is possible to characterize the impact of the maritime transport sector on air quality degradation in terms of pollutant concentrations. In fact, high pollutant concentrations can really affect environmental quality and human health in the surrounding areas to ports.

To calculate the polluting concentrations from ships and to assess the resulting air quality state in the area surrounding the port, this study was executed using the Gaussian model ISC. The methodology described in this analysis is quite general and can be considered as a significant appraisal tool for the local and national environmental authorities [21], since it can be employed to assess both the compliance of air quality with the limit values established by current legislation, and the influence of various scenarios of pollutant emission from arriving and sailing ships on the local air quality state. A case study has been developed for the port of Naples which is one of the busiest harbors of Italy.

\section{Ship emission and fuel change-over}

As widely known, the air emissions from marine traffic are regulated by Annex VI of MARPOL 73/78 (Marine Pollution), promulgated by the IMO in 1997 and subsequently amended. This regulation has been transposed in Europe by Directive 2005/33/EC and in Italy by DM. 205 of 6 November 2007.

In particular, these regulations govern the following issues:

- $\mathrm{SO}_{x}$ emissions of sulfur oxide and nitrogen oxides $\mathrm{NO}_{x}$ present in the exhaust gases of internal combustion engines.

- Emissions of substances that deplete the ozone layer in the atmosphere (fire and/or gases).

- Emissions from incinerators (it prohibits the incineration on board of certain products).

- Emissions of volatile organic compounds (VOCs) from the cargo area of tankers.

There are two limits on the emission value of $\mathrm{SO}_{x}$, one more compelling relative to ports and SECA areas and one less compelling relative to all other areas. To face this problem, more and more ships are being equipped with abatement systems to be installed on the engine exhaust gases stream. Such systems are for the most part seawater scrubbers, due to the greater capacity for $\mathrm{SO}_{x}$ absorption by sea water [22]. Such systems are still quite expensive, especially if installed on existing ships.

Ships that do not have systems to reduce $\mathrm{SO}_{x}$ emissions, such as sea water scrubbers, must therefore be prepared to 
use two different types of fuel, HFO and MDO (or MGO), the first for areas not subjected to emission control, the second for emission control areas and ports. For each fuel, ship emissions in terms of $\mathrm{NO}_{x}, \mathrm{SO}_{x}$ and PM present typical ranges and mean values. The analysis focused on large size two-stroke diesel engines. The choice depended on two reasons. The first is that we wanted to investigate precisely the effect of the changeover and this practice is carried out on the large two-stroke engines. The second is that most of $\mathrm{SO}_{x}$ and PM emitted in the port area of Naples is produced from precisely these kinds of engines. We referred to typical emissions level of engines of about $10,000 \mathrm{KW}$ power, as reported in Tables 1 and 2.

$\mathrm{NO}_{x}$ and $\mathrm{SO}_{x}$ values have been kindly provided by MAN DIESEL 14, PM ones are those reported in [23, 24]. $\mathrm{NO}_{x}$ emissions are not universal for any type of engine, depending on combustion process time and maximum combustion temperatures. However, the study primarily aims to understand how the production of pollutants decreases due to the changeover rather than accurately calculate the total production of $\mathrm{NO}_{x}$ in the area under investigation. In this sense the data of MAN engines have been considered as a good example, considering that not all ships have those emission values. Emissions reported in Tables 1 and 2 refer to four different power rate. Low power rate values are the most significant for the analysis because they are typical of the port approaching. Values for all the intermediate power rates can be evaluated with different approaches, as reported in [25].

We chose a $10,000 \mathrm{~kW}$ power rate as a mean value of all merchant ships transiting in the port.

When a ship is going to pass through an emission control area, it has to start a fuel change-over procedure, in time and in such a way that the engine will be burning MGO at the inlet of the area.

Fuel change-over must be performed carefully to avoid engine failure $[26,27]$. There is not a universal procedure to do it but some items must be monitored:
- Fuel viscosity must be kept within the range $2-20 \mathrm{cSt}$;

- Fuel temperature variation rate at fuel pump inlet, should not exceed $2{ }^{\circ} \mathrm{C} / \mathrm{min}$.

A low value of viscosity can cause:

- Reduced lubricant effectiveness, resulting in excessive wear and possible failure of the injection pump;

- Fuel leaks from pumps, valves and piston rings, preventing the ship to reach the maximum power;

when using low viscosity fuel (MGO), a way to maintain the viscosity above the minimum value of $2 \mathrm{cSt}$ (or the minimum specified by the engine manufacturer) is to install a cooler that will keep the fuel temperature below $40{ }^{\circ} \mathrm{C}$.

About the temperature of the fuel, typically, HFO is heated to about $150{ }^{\circ} \mathrm{C}$ and has to be changed to $\mathrm{MGO}$, used at about $40{ }^{\circ} \mathrm{C}$, so the temperature gap is about $110{ }^{\circ} \mathrm{C}$. Considering the allowed rate of change of $2{ }^{\circ} \mathrm{C} /$ min, the process of replacing the fuel should last a minimum 55 min to carry out safely.

A quick change from HFO to MGO can cause overheating of MGO which causes a rapid loss of viscosity and gassing in the fuel system. Likewise, a too rapid a change from unheated MGO to HFO can lead to excessive cooling of HFO and therefore excessive viscosity to the injectors resulting in possible loss of power or shutdown. Therefore it is recommended to make the change of fuel with the engine at lower power levels. The load, however, should not be too low otherwise the mixing time of HFO and MGO in the service system increases with a consequent risk of precipitation of asphaltenes, clogging of filters and therefore loss of power or engine failure. Usually changeover is done on maneuverable speed and the fuel viscosity should be as close as recommended by engine manufacturer. The ship should be on low sulfur fuel before entering in SECA area or ports.

Another issue related to the use of low sulfur fuels, is the need to use a lubricating oil with different Base Number (BN). Because of the high acid levels on the cylinder liner
Table 1 Emissions from HFO combustion in a $9800 \mathrm{~kW}$ engine

Table 2 Emissions from MGO combustion in a $9800 \mathrm{~kW}$ engine

\begin{tabular}{lllll}
\hline & Engine load 100 \% & Engine load 75 \% & Engine load 50 \% & Engine load 25 \% \\
\hline Engine power $(\mathrm{kW})$ & 9800 & 7350 & 4900 & 2450 \\
$\mathrm{NO}_{x}(\mathrm{~g} / \mathrm{kWh})$ & 14.60 & 15.70 & 17.50 & 17.20 \\
$\mathrm{SO}_{x}(\mathrm{~g} / \mathrm{kWh})$ & 2.96 & 2.91 & 3.33 & 3.14 \\
$\mathrm{PM}(\mathrm{g} / \mathrm{kWh})$ & 1.7 & 1.9 & 2.2 & 2.4 \\
\hline
\end{tabular}

\begin{tabular}{lllll}
\hline & Engine load 100\% & Engine load 75 \% & Engine load 50 \% & Engine load 25\% \\
\hline Engine power $(\mathrm{kW})$ & 9800 & 7350 & 4900 & 2450 \\
$\mathrm{NO}_{x}(\mathrm{~g} / \mathrm{kWh})$ & 12.98 & 14.71 & 15.43 & 13.53 \\
$\mathrm{SO}_{x}(\mathrm{~g} / \mathrm{kWh})$ & 0.178 & 0.175 & 0.177 & 0.189 \\
$\mathrm{PM}(\mathrm{g} / \mathrm{kWh})$ & 0.3 & 0.5 & 0.7 & 0.9 \\
\hline
\end{tabular}


when using heavy fuel oil with a $2 \%$ sulfur content, a lubricating oil with $\mathrm{BN}$ (or TBN) of about 70 is recommended. Such BN value ensures the neutralization of sulfuric acid $\left(\mathrm{H}_{2} \mathrm{SO}_{4}\right)$ and sulfur trioxide formed by $\mathrm{SO}_{2}$ and $\mathrm{SO}_{3}$. However, this $\mathrm{BN}$ (or TBN) is inadequate for low sulphur fuels: a prolonged operation with low sulphur fuel oil and lubricating oil with $\mathrm{BN}$ (or TBN) of 70 could cause the formation of calcium deposits $\left(\mathrm{CaCO}_{3}\right)$ and so a considerable abrasive wear. In case of long-term operation with low sulfur fuels, it is recommended to switch to a lubricating oil with $\mathrm{BN}$ (or TBN) 40 or 50 . It is generally recommended to use a lubricant with BN (or TBN) 40.50 or even for the short term operation if the sulfur content is less than $1 \%$.

HFO operation temperature is dependent on its viscosity which can vary on average from 180 to $720 \mathrm{cSt}$, the higher the viscosity, the higher the operation temperature. Before starting the change-over procedure form $\mathrm{HFO}$ (up to $120{ }^{\circ} \mathrm{C}$ for the most viscous) to $\mathrm{MGO}$ (room temperature). It is necessary to reduce the temperature of the fuel heating lines gradually; it takes about 2-3 h in the worst case. To protect the fuel injection system against rapid temperature changes, which can cause the bonding of the fuel valves, piston fuel pump and intake valve, the changeover should be performed as follows:

- Preheating of diesel fuel in the tank at about $50{ }^{\circ} \mathrm{C}$ (in practice this almost never works: diesel fuel is up to $35-40{ }^{\circ} \mathrm{C}$ (engine room temperature) and the mixing tank has a purpose of gradually changing the fuel);

- Interruption of steam to fuel preheating system;

- Reduction of engine load at 3/4 load MCR (Maximum Continuous Rating);

- Transition to MGO when the heavy fuel oil temperature in the preheater has dropped by about $25^{\circ} \mathrm{C}$ but, in any case, not less than a minimum temperature which depends on fuel type.

So, in summary, to complete the fuel change-over, assuring that all HFO residue is consumed in the fuel system, the procedure must begin, in general, at least $3 \mathrm{~h}$ before the SECA area and the fuel line should be started to be heated at least $2 / 3 \mathrm{~h}$ before the start of procedure.

About the procedure of the changeover from MGO to $\mathrm{HFO}$, to protect the injection device against rapid changes of temperature, which may cause bonding/seizing of the fuel valves, pistons of the fuel pump and the intake valves, the following steps are to be carried out:

- Ensure that the heavy oil in the tank of service is at the correct operating temperature;

- Reduce the engine load to $3 / 4$ of MCR;

- Heat the oil up to $60-80{ }^{\circ} \mathrm{C}$ (depending on fuel type) adjusting the preheating so as to give a temperature increase of about $2{ }^{\circ} \mathrm{C}$ per min.
On the basis of all these considerations, we can assume that fuel change-over procedure is carried out in a few hours, in both cases.

\section{The emission dispersion model}

Forecasting the air quality state in urban environment as a result of several pollution sources (industries, transports, and residential) involves a valuation of the dispersion, chemical reactions, and natural removal processes which affect the concentrations of the air pollutants in the space around the same sources after the release. The emission dispersion models investigate the physical aspects concerning the atmospheric diffusion of the air pollutants with a deterministic method accounting of meteorological parameters too. The basic structure of these dispersion models is characterized by a database of algorithms that can describe in easy way the several composite phenomenon of the gas atmospheric dispersion. The input data of these simulation tools are the meteorological parameters (suitably treated) obtained from the weather stations distributed on the territory, and the emission levels of the air pollutants. The output values are the concentrations of the same air pollutants in the areas object of the study, and their temporal variation. The particular simulation model to use for the study of the pollutant dispersion and concentration in atmosphere must be chosen based on several aspects, that are: the updating and the accurateness of the existing data (emission inventories and climatological factors), the orography of the area under examination, the features of the emissive sources (point or non-point sources), and the field of application (industrial or urban) [28].

The specific dispersion model suggested for the definite targets of this investigation is the Gaussian model ISC (Industrial Source Complex). This particular dispersion model is commonly used for similar studies, and its general mathematical formulation is generally used to simulate the horizontal and vertical dispersion of air pollutants downwind from the emissive sources. Gaussian model deals dispersion of air pollutants as being carried downwind in a definite plume, under vertical and horizontal mixing in the neighboring atmosphere: the plume of air pollutants diffuses vertically and horizontally, with a consequent decrease in concentration as it moves downwind. Besides, mixing with the nearby atmospheric air is greatest on the border of the plume, so causing lesser concentrations outward from the center of the plume, and this reduction in pollutant concentrations outward from the center is analyzed through a Gaussian ("normal") statistical distribution.

While the central statement of the Gaussian dispersion method, namely the hypothesis of "normal" distribution of the pollutant concentrations, occurs only in completely 
ideal situations of atmosphere homogenous turbulence, the softwares based on this mathematical structure are calculation tools of broadest use since they are characterized from an easy mathematical formulation. In general, the results obtained with Gaussian dispersion models are in accord with experimental data, above all for estimations in long-term version. Instead, the Gaussian models aren't much appropriate to describe the dispersion process of unstable pollutants in not homogenous conditions of atmosphere and without flat topography.

The ISC model simulates the pollutant dispersions from varied sources that can be present at a characteristic industrial source complex. The base of this particular Gaussian model is the steady-state plume equation that is employed to describe point source emissions from stacks, also considering aerodynamic downwash due to adjacent structures.

The ISC Short Term model accepts hourly meteorological data records to define the conditions for plume rise, transport, diffusion, and deposition. The concentrations calculated for each source at each receptor are summed to obtain the total concentration produced at each receptor by the combined source emissions. For a steady-state Gaussian plume, the concentration at downwind distance $\mathrm{x}$ (meters) and crosswind distance y (meters) is given by:

$C(x, y)=\frac{Q}{\pi u \sigma_{\mathrm{y}} \sigma_{\mathrm{z}}} \mathrm{e}^{\left(\frac{-H^{2}}{2 \sigma_{\mathrm{z}}^{2}}\right)} \mathrm{e}^{\left(\frac{-y^{2}}{2 \sigma_{\mathrm{y}}^{2}}\right)}$

- $C(x, y)$ : pollutant concentration to the ground level in $(x, y)$ point $\left(\mathrm{g} / \mathrm{m}^{3}\right)$

- $Q$ : pollutant emission rate (mass per unit time) $(\mathrm{g} / \mathrm{s})$;

- $H$ : effective source elevation (m);

- $u$ : mean wind speed at release height $(\mathrm{m} / \mathrm{s})$;

- $\sigma_{\mathrm{y}}$ : lateral dispersion coefficient (m);

- $\sigma_{\mathrm{z}}$ : vertical dispersion coefficient $(\mathrm{m})$;

For the definite requests of the present study, the ISC model was utilized in the long-term version that, instead of hourly input data, uses meteorological data that have been grouped into joint frequencies of event for the particular wind speed, atmospheric stability and wind direction classes. In the long-term version, the area neighboring a continuous source of air pollutants is shared into zones of equivalent angular width consistent to the sectors of the seasonal and annual frequency distributions of wind speed, wind direction, and atmospheric stability classes. The hourly meteorological data, then, were subjected to statistical processing to obtain the mean values of the various parameters in the year. Therefore, values of wind speed, wind direction and atmospheric stability are calculated by the model as average values on the whole year.

\section{Case study: the port of naples}

The effects of ship emissions on coastal air quality have been evaluated within a number of research activities all over the world, as reported in [29-33]. All of these suggest that a non-negligible percentage of air pollutants may come from ships in those areas, comparing with emissions from all different sources.

The present work has been focused on pollutant emitted by merchant ships transiting in the port of Naples (Fig. 1). Analysis domain (Fig. 2) is a $10 \mathrm{~km} \times 10 \mathrm{~km}$ area including the piers for large ships, the coastal area adjacent and the sea area interested by ship maneuvers approaching the port.

This domain has been discretized with a $32 \times 32$ elements square grid and three main routes have been considered for ships entering and leaving the port. As previously said, we used a Gaussian model ISC [34] to assess the production and dispersion of $\mathrm{NO}_{x}, \mathrm{SO}_{x}$ and $\mathrm{PM}$ along the routes.

All the meteorological input data required to simulate the dispersion of these air pollutants (for instance: wind direction and speed, temperatures and atmospheric stability classes) were gathered at the weather station of Naples airport, and subsequently grouped into joint frequencies of occurrence.

Nevertheless, the Gaussian mathematical approach used in this analysis is generally characterized by certain limits, regarding the appraisal of atmospheric gas dispersion. Gaussian models, in fact, don't deal the dispersion of air pollutants in the presence of buildings and obstacles, and for complex orography conditions. The simulated pollutant concentrations must be considered as spatially averaged results, whereas, within a street canyon the real concentrations can diverge considerably. But then, an easy dispersion model can simplify the assessment of the hourly time series for 1 year of meteorological and emission conditions, that is necessary for the calculation of statistical parameters, so as demarcated in national air quality guidelines.

This modeling approach of the Gaussian dispersion model, consequently, can be considered as a valid calculation tool for the national environmental management, since it can be used to evaluate the agreement of air quality state with the guidelines and limit values (together with the measured concentrations), and the impact of new emission activities on the pollutant concentrations.

The result of the simulation model is still suffering from a certain degree of uncertainty due to the composition of the approximation inherent to the model (dictated by the inability to perfectly describe the physical phenomena) and the uncertainty associated with the input data, such as the 
Fig. 1 The port of Naples (Google)

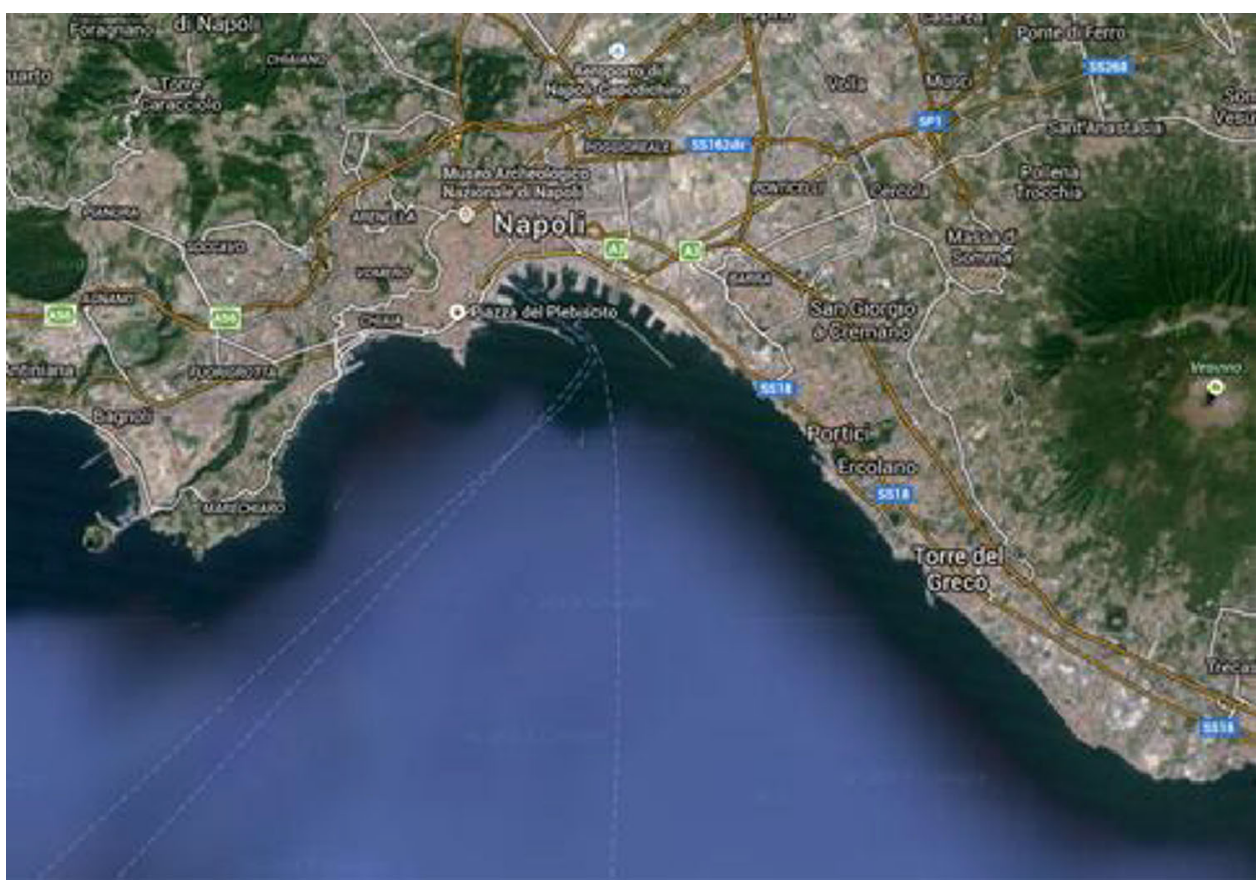

Fig. 2 Analysis domain with elements square grid in evidence

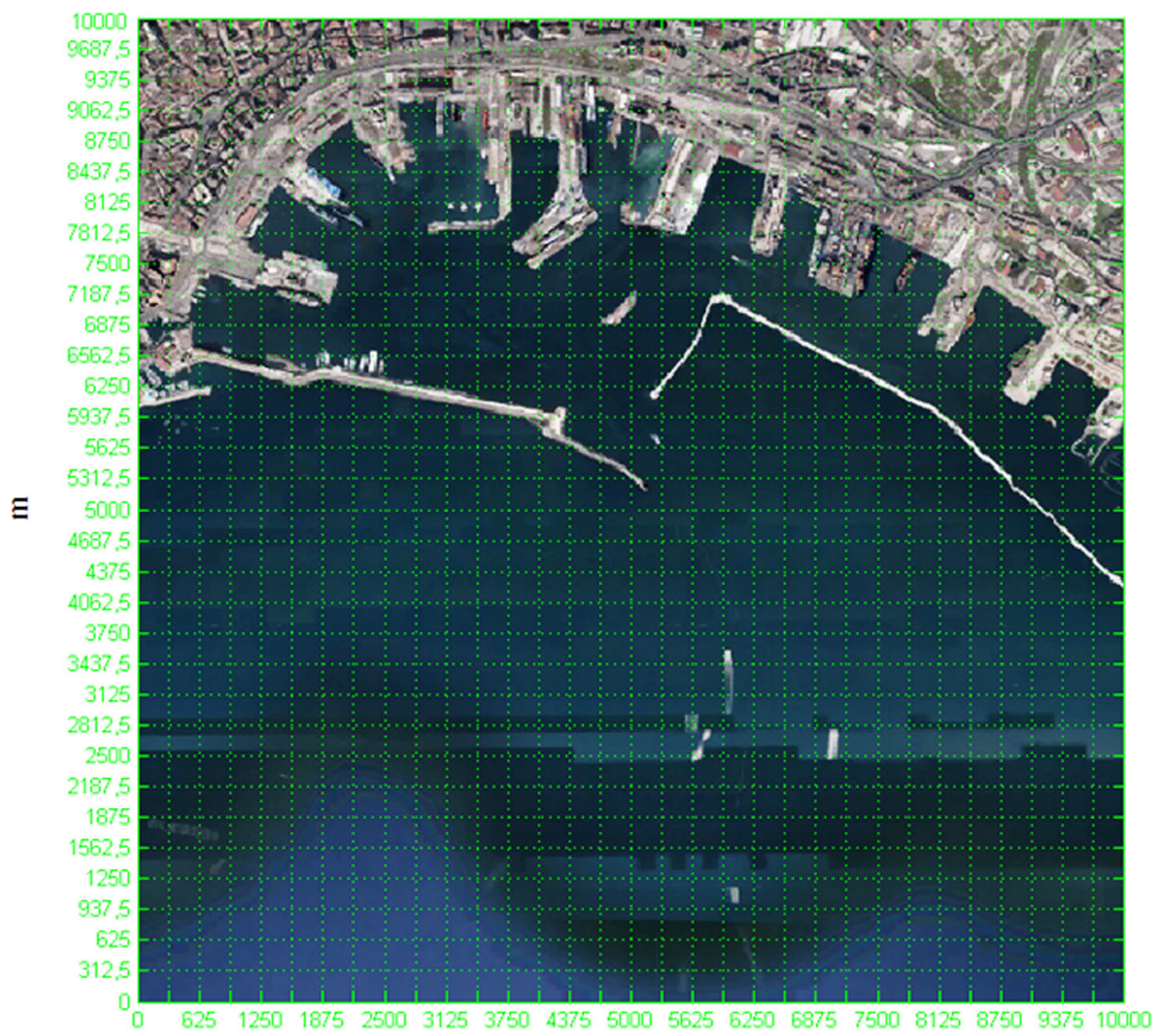

$\mathrm{m}$

emissions and meteorological parameters. Furthermore, the model used is valid for steady-state condition, that is for one or more fixed sources that emit continuously. The chimneys of the vessels are not fixed but moving sources, moreover emission rate are quite variable during maneuvering depending on power rate and tugs situations. For 
Fig. 3 Approaching routes (green arrows) and emission source points (red circular spots) on the analysis domain

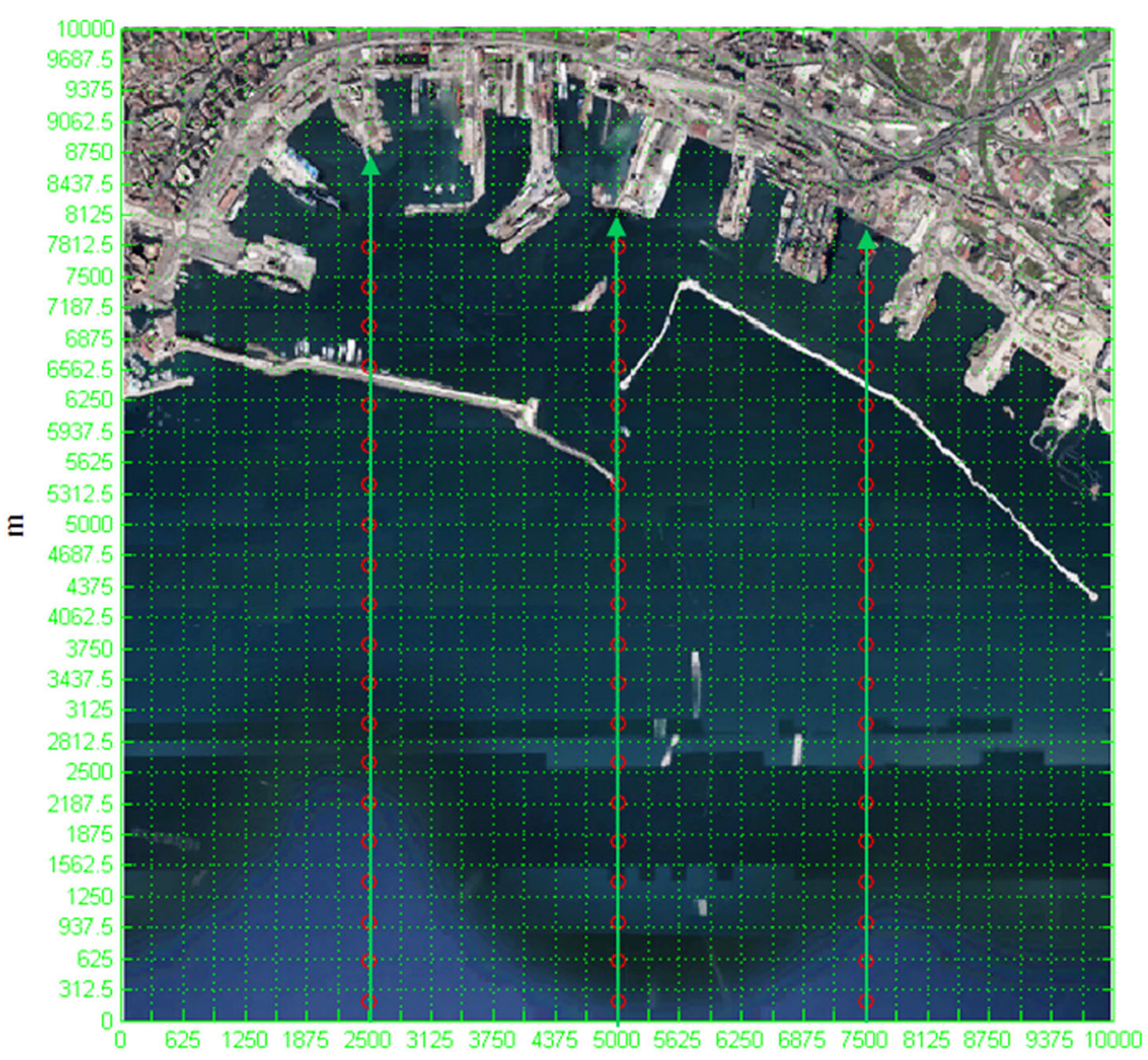

$\mathrm{m}$ this reason, to apply the steady-state model to this variable contest, chimneys have been simulated by a number $(60$ and 20 for each main route) of fixed emission sources along the main routes, emitting the same total amount of $\mathrm{NO}_{x}$, $\mathrm{SO}_{x}$ and $\mathrm{PM}$ produced by the ship traffic. Routs and emission sources are reported in Fig. 3.

Starting from traffic data acquired by Maritime Coastal Authority of the Port of Naples, we consider about 10,500 (2014 data) ships entering the port in a year. That means 30 ships entering and 30 ships leaving in a day.

The total emission of each pollutant emitted in the in a day area, i.e., for $\mathrm{SO}_{x}$, can be calculated by:

$E_{\mathrm{SO}_{x}, \mathrm{~d}}\left[\frac{\mathrm{g}}{\mathrm{day}}\right]=E_{\mathrm{SO}_{x}}\left[\frac{\mathrm{g}}{\mathrm{kWh}}\right] \cdot P[\mathrm{~kW}] \cdot \frac{L[\mathrm{~km}]}{v\left[\frac{\mathrm{km}}{\mathrm{h}}\right]} \cdot n_{\mathrm{s}}\left[\frac{1}{\text { day }}\right]$

where $E_{\mathrm{SO}_{x}}$ is the emission rate of the ship engine, $P$ is the actual power rate of the ship engine, $L$ is the route length, $v$ is the ship velocity along the route and $n_{\mathrm{s}}$ is the total number of ships crossing the area in a day $(30+30$ in the case study).

Maneuvering the vessel, both on entry and exit from port is marked by quite variable power rates of the engine. As a reasonable approximation, we considered that ships entering and leaving the port have the main engine at $25 \%$ of its power rate and a low velocity of about 5 miles per hour $(9 \mathrm{~km} / \mathrm{h})$.

Spreading the total emission along the routes, each virtual source point emits continuously with the following rate:

$E_{\mathrm{SO}_{x}, \text { vsp }}\left[\frac{g}{h}\right]=\frac{E_{\mathrm{SO}_{x}, \mathrm{~d}}\left[\frac{\mathrm{g}}{\mathrm{day}}\right]}{n_{\mathrm{vsp}} \cdot 24\left[\frac{\mathrm{h}}{\mathrm{day}}\right]}$

Once known the emission rates of of $\mathrm{NO}_{x}, \mathrm{SO}_{x}$ and $\mathrm{PM}$, the average height and diameter of the chimneys, the average temperature and speed of the exhaust gas, the model provided the concentration maps of such pollutants above the entire domain $(10 \mathrm{~km} \times 10 \mathrm{~km})$. Three cases have been examined, as reported:

1. HFO case burning HFO (0.6\% sulfur content) during the whole approaching maneuver to the port; in this case the fuel changeover takes place within the port;

2. HFO-MGO case gradual fuel switch from HFO to MGO during the whole approaching maneuver;

3. MGO case burning MGO (0.15 sulfur content) during the whole approaching maneuver to the port; in this case the fuel changeover takes place before the approaching maneuver. 
For the second case, we assumed a linear variation of emission rates between the values assumed for HFO and MGO.

The dispersion of the considered pollutants in atmosphere was investigated on maps with receptors located at $2 \mathrm{~m}$ altitude; the application of the Gaussian model on the selected area has determined the pollutant concentrations due to the arriving and sailing ships. The chief results and elaborations obtained using this model are exposed in the maps of the following figures (Figs. 4, 5, 6, 7, 8, 9, 10, 11, 12), in that

Fig. $4 \mathrm{NO}_{x}$ concentration. $\mathrm{HFO}$ case

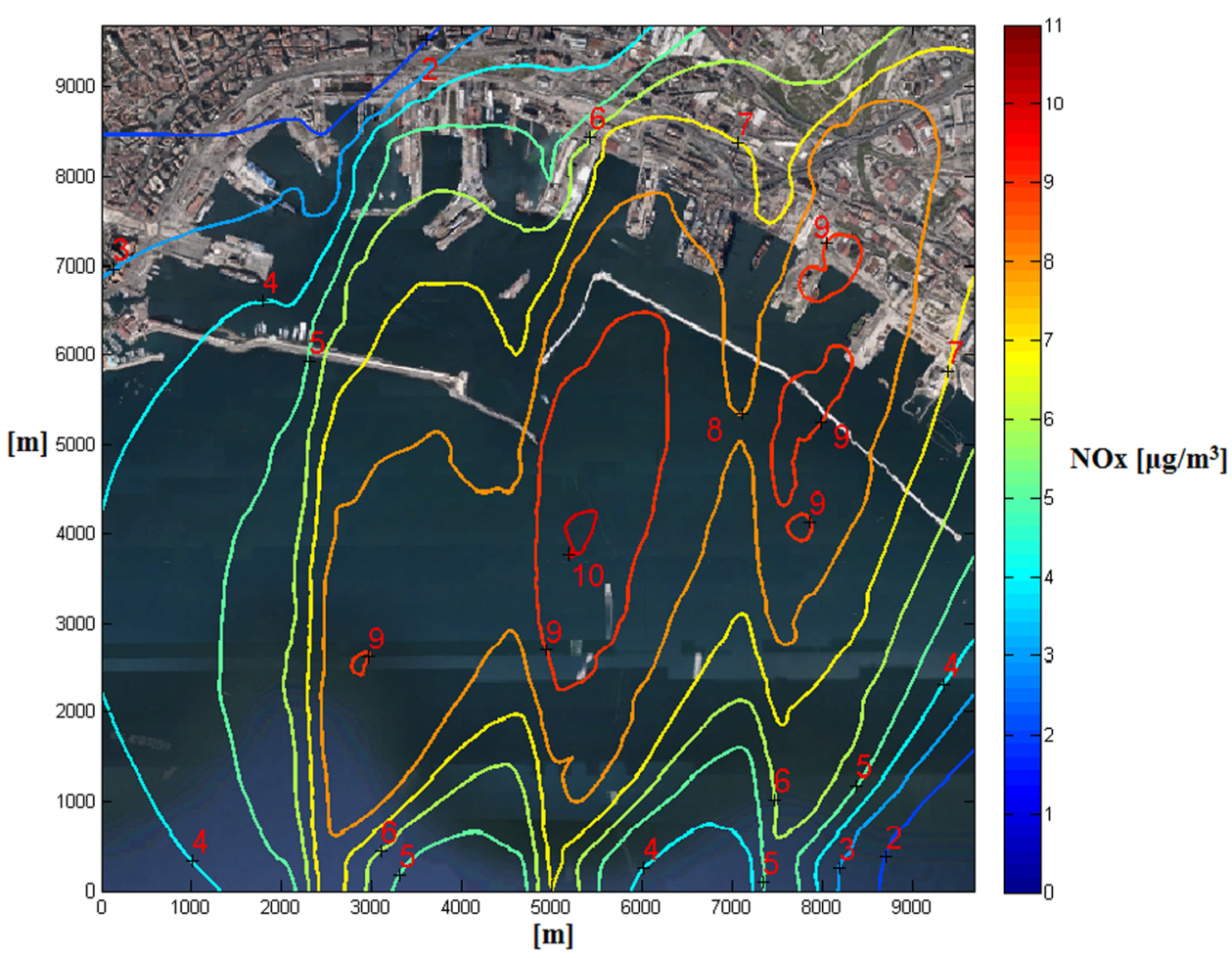

Fig. $5 \mathrm{NO}_{x}$ concentration HFO-MGO case

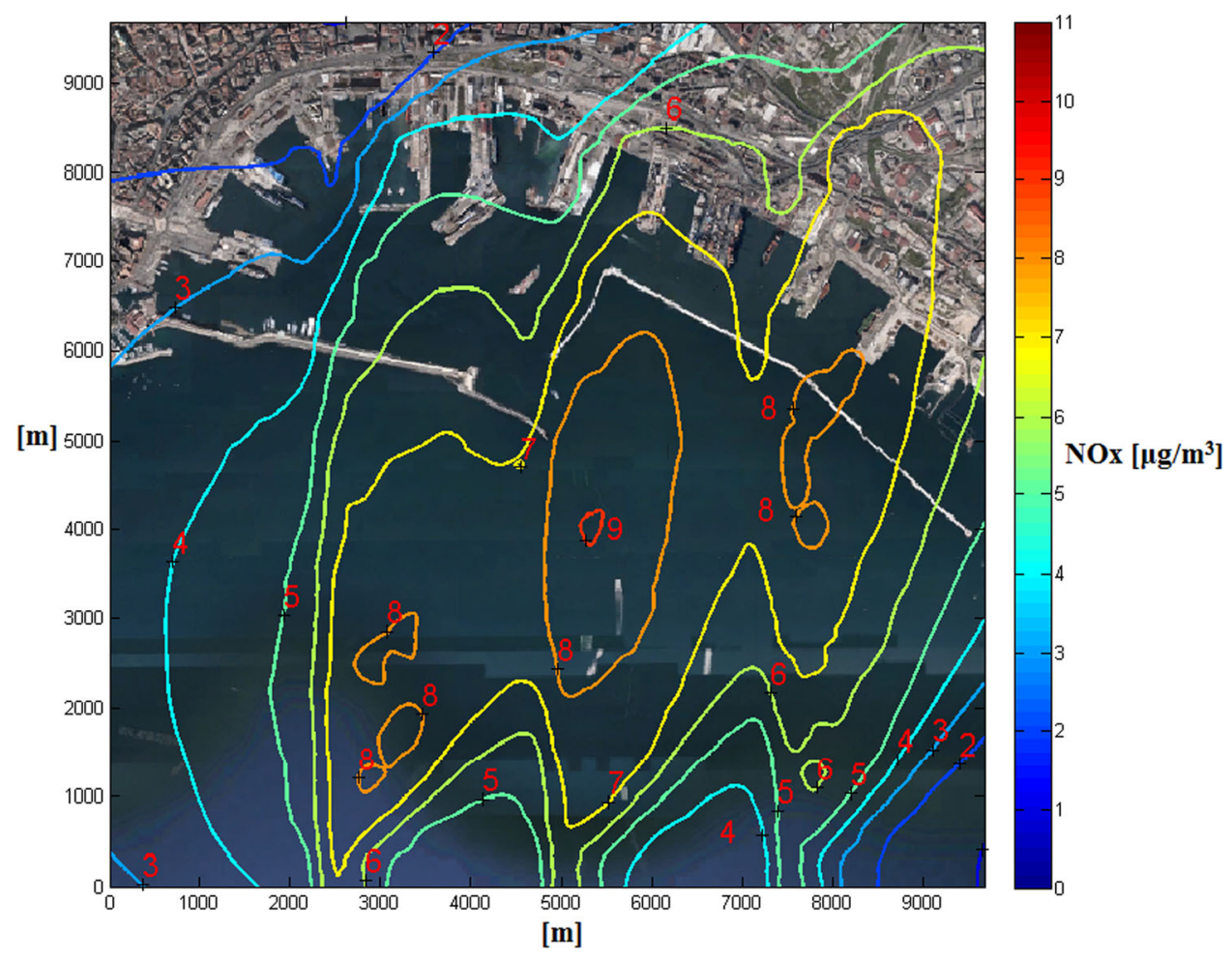


it's possible to appraise the average concentrations in $\mu \mathrm{g} /$ $\mathrm{m}^{3}$ of $\mathrm{NO}_{x}, \mathrm{SO}_{x}$ and PM at ground level in the form of isoconcentration lines for the examined cases. The pollutant concentrations shown in these figures must be considered as average values in the whole year.
By the analysis of results, the HFO-MGO case over the coastal zone gives better results than those expected. This can be recognized by comparing Figs. 13 and 14. Figure 13 reports the average concentration value of the specific pollutants over the whole domain against fuel type, while
Fig. $6 \mathrm{NO}_{x}$ concentration. MGO case

Fig. $7 \mathrm{SO}_{x}$ concentration. $\mathrm{HFO}$ case
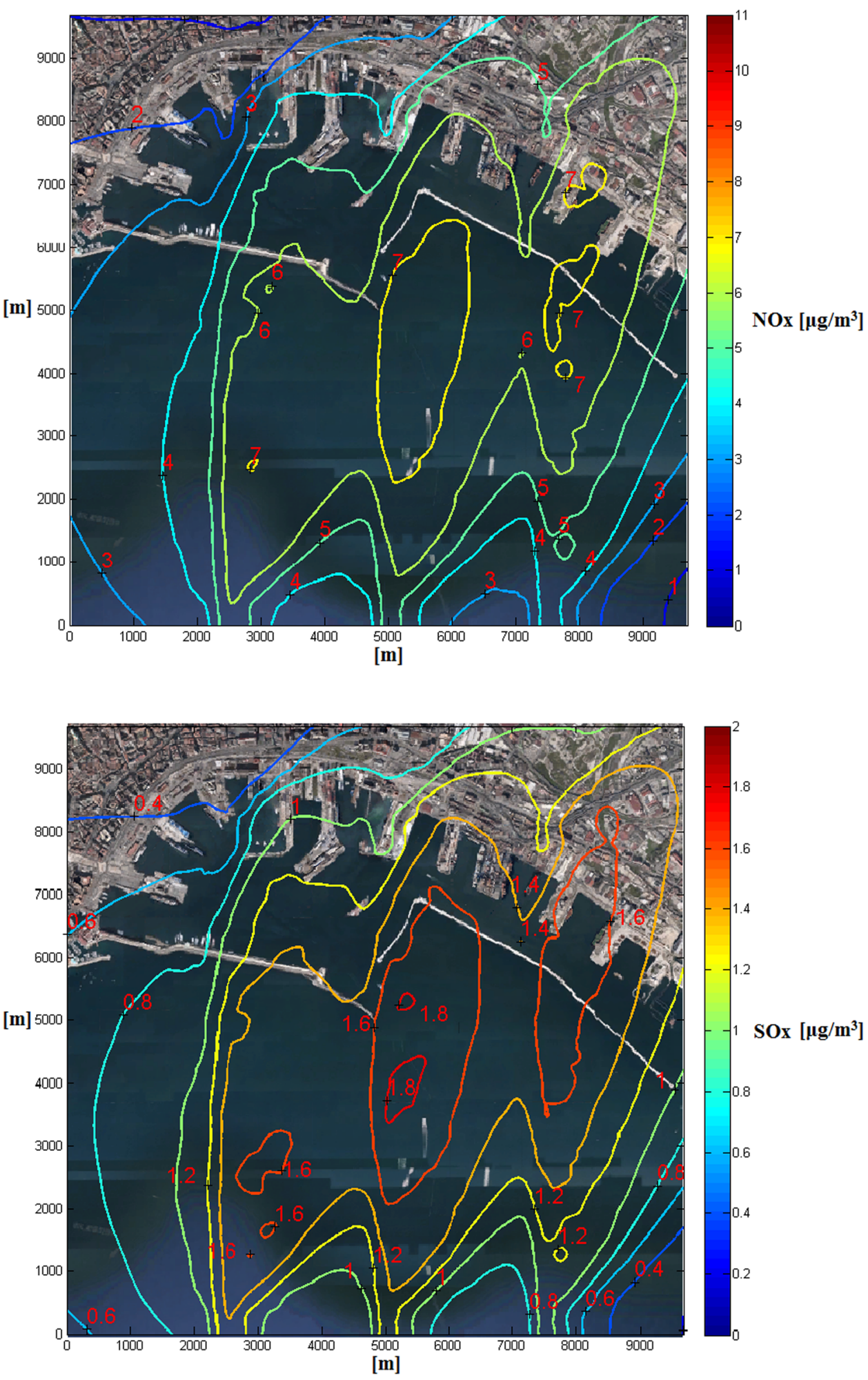
Fig. $8 \mathrm{SO}_{x}$ concentration. HFO-MGO case

Fig. $9 \mathrm{SO}_{x}$ concentration. MGO case
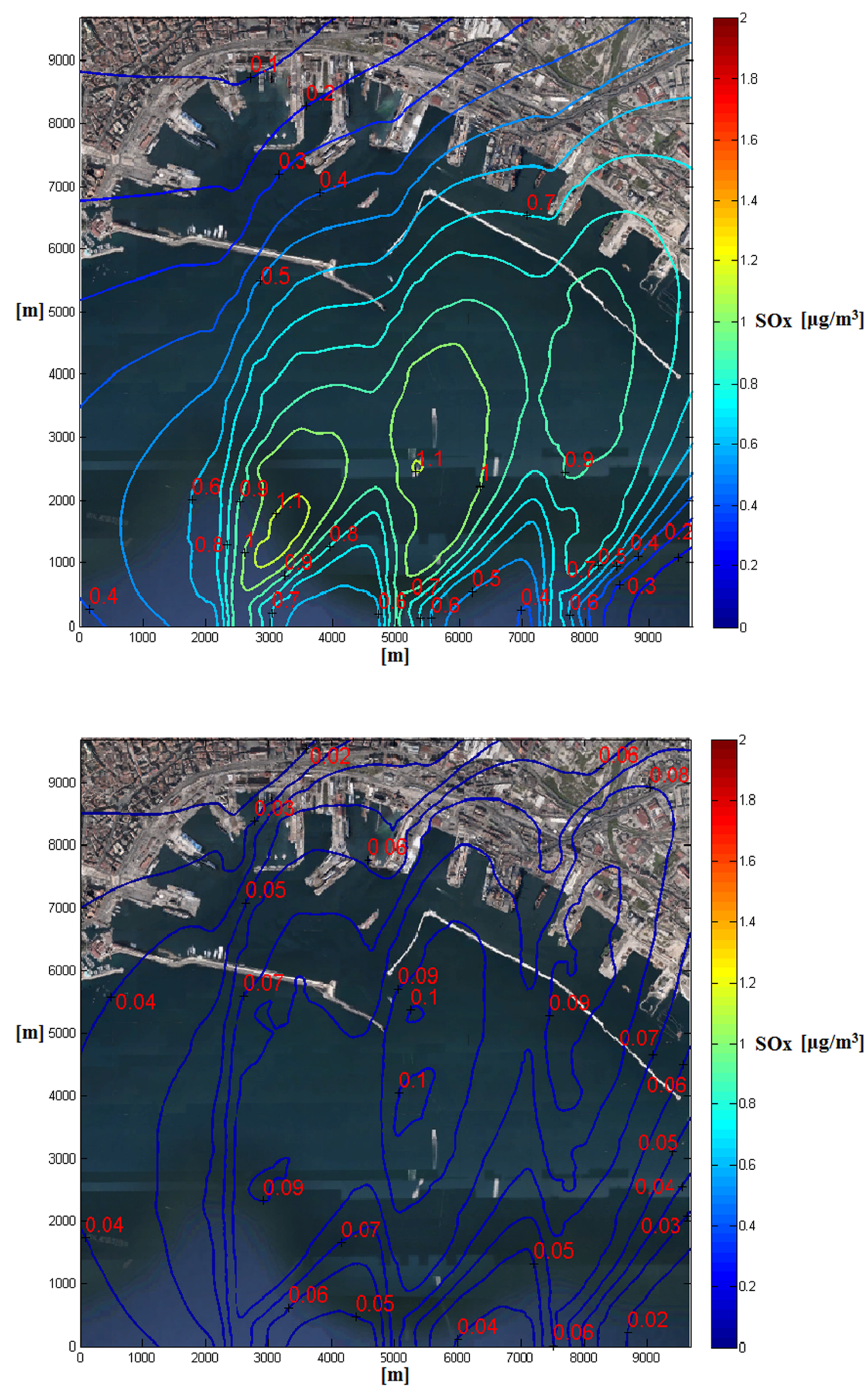

Fig. 14 reports the same parameters but only over the coastal zone. Over the coastal area, the average concentrations of $\mathrm{NO}_{x}, \mathrm{SO}_{x}$ and PM for the HFO-MGO Case, does not have a linear reduction as it was presumed and as it is for the whole domain. Therefore the change of the fuel during the entrance to the port involves a considerable 
Fig. 10 PM concentration. HFO case

Fig. 11 PM concentration. HFO-MGO case
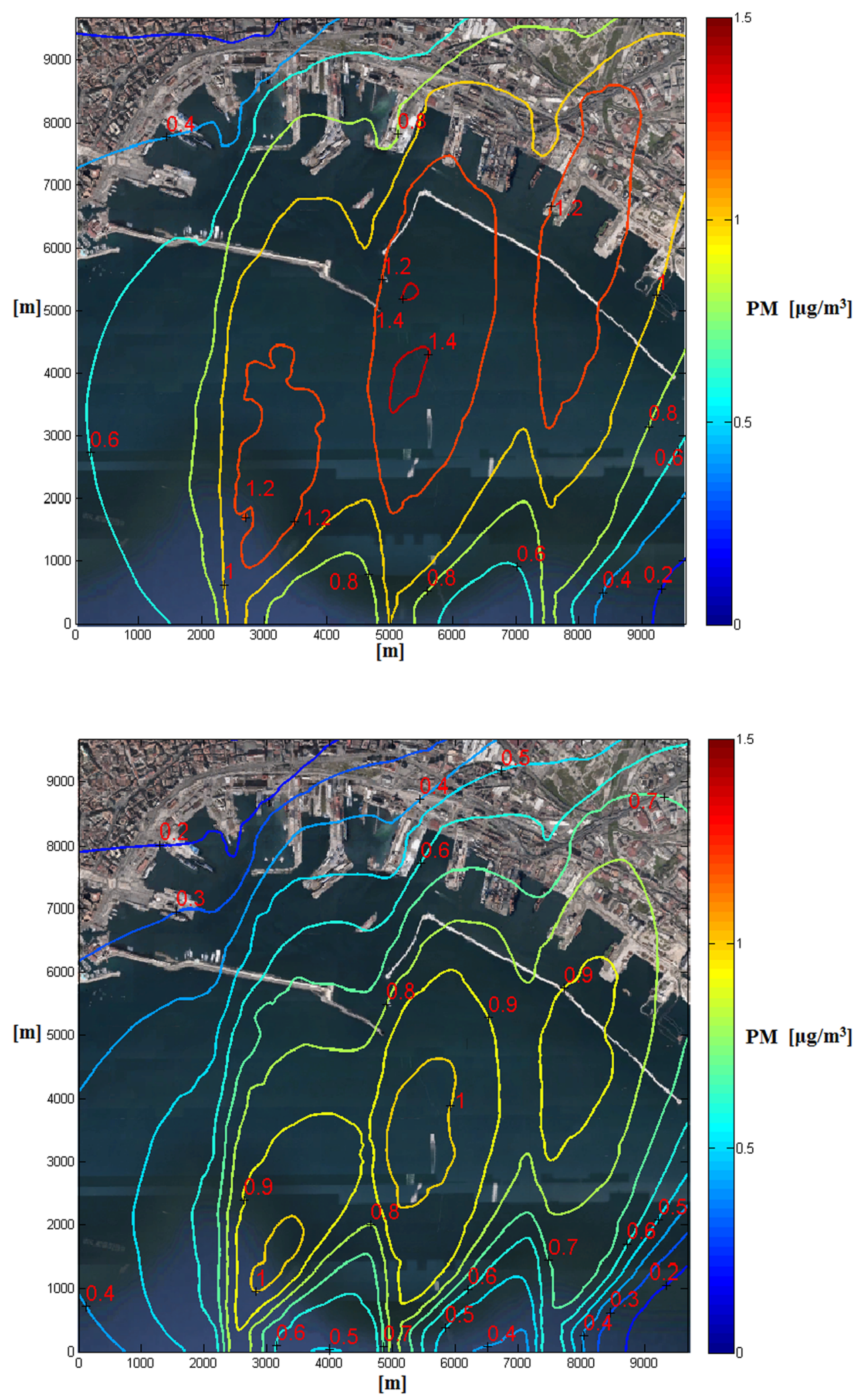

benefit on air quality state (quantified in these figures) greater than that expected, in terms of reducing the concentrations of $\mathrm{SO}_{x}, \mathrm{NO}_{x}$ and $\mathrm{PM}$.
Although these computational results should be validated by comparison with registered data, preliminarily it is necessary an analysis to evaluate the contribution of 
Fig. 12 PM concentration. MGO Case

Fig. 13 Average pollutant concentrations over the whole analysis domain against fuel type
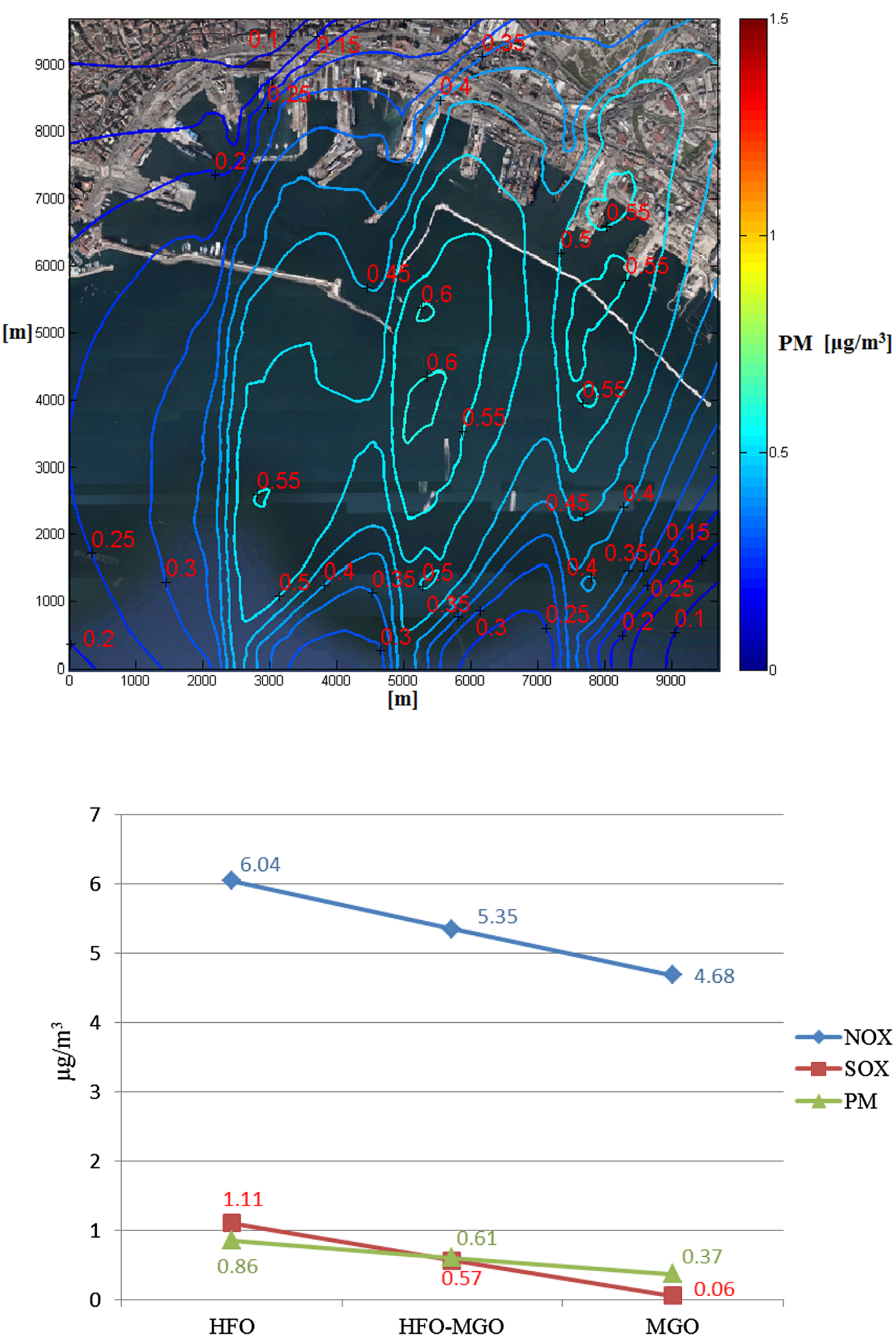

marine engines on the total air pollutants produced in the area under investigation. The air quality state and pollutant concentrations over coastal area of Naples, in fact, are affected by many other emissive sources, above all emissions from the road transport sector. However, to meet this essential purpose, the next phase of this activity will be the experimental measurements of pollutant concentrations off the coast, where the effect of other emissive sources can be considered negligible.

About the generalization and extension of these results to other cases, it is clear that this possibility depend on the local factors that affect pollutant concentrations (meteorological parameters and marine traffic) in the several areas under examination. However, the data obtained in this 
Fig. 14 Average pollutant concentrations over the coastal area against fuel type

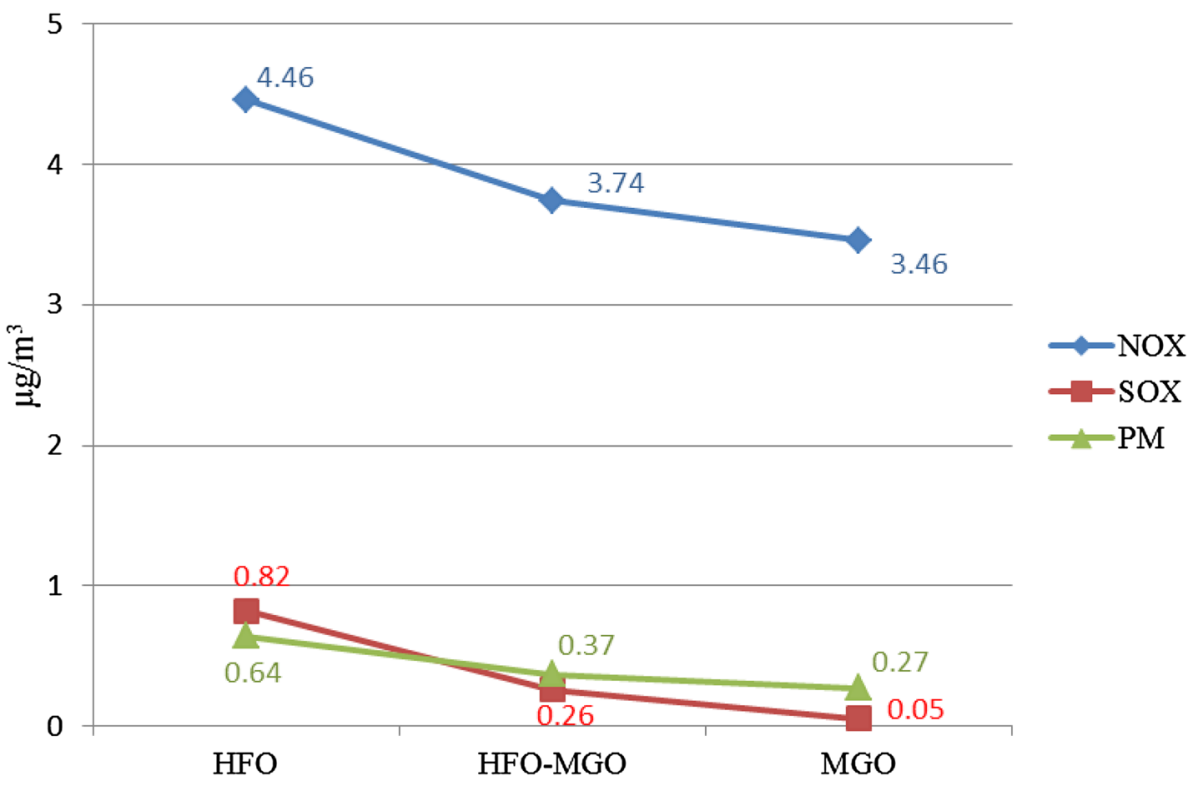

study can supply first interesting results in coastal areas characterized by marine traffic conditions similar to those detected in the port of Naples; subsequently, the application of the entire calculation procedure explained in this paper will provide more detailed information.

\section{Conclusions}

Ship traffic contributes significantly to pollutant emissions into the atmosphere. This issue is particularly important in the vicinity of coastal areas and especially in ports. The current regulations require that emissions in port areas are contained within narrower limits than the open sea. As seen, the standard can be met or by installing on board an emission abatement system (such as scrubbers for $\mathrm{SO}_{x}$ and PM, SCR for $\mathrm{NO}_{x}$ ), or by burning a "cleaner" fuel within those areas. The present study examined the latter case, by analyzing the problems related to the changeover of the fuel.

In particular we analyzed three different fuel changeover procedures, considering for each of them the ecological impact of vessel traffic on the port area. We examined the case study on the port of Naples, by calculating the production of $\mathrm{SO}_{x}, \mathrm{NO}_{x}$ and $\mathrm{PM}$ connected to the traffic of merchant ships into and out of the harbor and evaluating their dispersion in the domain of inquiry and in particular in the coastal area. The mode which operates fuel change-over during the approach to the port has shown environmental benefits higher than expected, especially with respect to the coastal area.

The methodology and all the results provided by this analysis are valid assessment tools to study air quality state and to define possible remediation plans in areas characterized by non-compliance with the limit values settled by recent legislations. Besides, the analysis method worked and the data collected can be of great help to the improvement of emission regulations on maritime traffic, especially for coastal areas.

Acknowledgments We are very grateful to the Port Authority of Naples for the information provided about the maritime traffic and to MAN Diesel for data related to engine emissions at part load and for different fuels.

Open Access This article is distributed under the terms of the Creative Commons Attribution 4.0 International License (http://crea tivecommons.org/licenses/by/4.0/), which permits unrestricted use, distribution, and reproduction in any medium, provided you give appropriate credit to the original author(s) and the source, provide a link to the Creative Commons license, and indicate if changes were made.

\section{References}

1. Fuglestvedt, J.S., Shine, K.P., Berntsen, T., Cook, J., Lee, D.S., Stenke, A., Skeie, R.B., Velders, G.J.M., Waitz, I.A.: Transport impacts on atmosphere and climate: Metrics. Atmos. Environ. 44, 4648-4677 (2010)

2. Bailey, D., Solomon, G.: Pollution prevention at ports: clearing the air. Environ. Impact Assess. Rev. 24, 749-774 (2004)

3. Iodice, P., Senatore, A.: Experimental-analytical investigation to estimate an emission inventory from road transport sector. IAENG Transactions on Engineering Sciences-Special Issue of the International MultiConference of Engineers and Computer Scientists, IMECS 2013 and World Congress on Engineering, WCE 2013, pp 141-149 (2014)

4. Corbett, J.J., Koehler, H.W.: Updated emissions from ocean shipping. J. Geophys. Res. 108(D20), 4650 (2003)

5. Vutukuru, S., Dabdub, D.: Modeling the effects of ship emissions on coastal air quality: a case study of southern California. Atmos. Environ. 42, 3751-3764 (2008) 
6. Dore, A.J., Vieno, M., Tang, Y.S., Dragosits, U., Dosio, A., Weston, K.J., Sutton, M.A.: Modelling the atmospheric transport and deposition of sulphur and nitrogen over the United Kingdom and assessment of the influence of $\mathrm{SO}_{2}$ emissions from international shipping. Atmos. Environ. 41, 2355-2367 (2007)

7. Derwent, R.G., Stevenson, D.S., Doherty, R.M., Collins, W.J., Sanderson, M.G., Johnson, C.E., Cofala, J., Mechler, R., Amann, M., Dentener, F.J.: The contribution from shipping emissions to air quality and acid deposition in Europe. Ambio 34, 54-59 (2005)

8. Endresen, O., Sorgard, E., Sundet, J.K., Dalsoren, S.B., Isaksen, I.S.A., Berglen, T.F., Gravir, G.: Emission from international sea transportation and environmental impact. J. Geophys. Res. 108(D17), 4560 (2003)

9. Lu, G., Brook, J.R., Alfarra, M.R., Anlauf, K., Leaitch, W.R., Sharma, S., Wang, D., Worsnop, D.R., Phinney, L.: Identification and characterization of inland ship plumes over Vancouver, BC. Atmos. Environ. 40, 2767-2782 (2006)

10. Streets, D.G., Guttikunda, S.K., Carmichael, G.R.: The growing contribution of sulfur emissions from ships in Asian Waters, 1998-2005. Atmos. Environ. 34, 4425-4439 (2000)

11. Eyring, V., Kohler, H.W., Lauer, A., Lemper, B.: Emissions from international shipping: 2. Impact of future technologies on scenarios until 2050. J. Geophys. Res. 110(D17), D17306 (2005)

12. Giakoumis, E.G., Alafouzos, A.I.: Study of diesel engine performance and emissions during a Transient Cycle applying an engine mapping-based methodology. Appl. Energy 87, 1358-1365 (2010)

13. Walsh, C., Bows, A.: Size matters: exploring the importance of vessel characteristics to inform estimates of shipping emissions. Appl. Energy 98, 128-137 (2012)

14. Raptotasios, S.I., Sakellaridis, N.F., Papagiannakis, R.G., Hountalas, D.T.: Application of a multi-zone combustion model to investigate the $\mathrm{NO}_{x}$ reduction potential of two-stroke marine diesel engines using EGR. Appl. Energy 157, 814-823 (2015)

15. EEA: The impact of international shipping on european air quality and climate forcing, p. 88. EEA, Copenhagen (2013)

16. Agrawal, H., Malloy, Q.G.J., Welch, W.A., Miller, J.W., Cocker, D.R.: In-use gaseous and particulate matter emissions from a modern ocean going container vessel. Atmos. Environ. 42, 5504-5510 (2008)

17. Agrawal, H., Welch, W.A., Miller, J.W., Cocker, D.R.: Emission measurements from a crude oil tanker at sea. Environ. Sci. Technol. 42, 7098-7103 (2008)

18. Petzold, A., Hasselbach, J., Lauer, O., Baumann, R., Franke, K., Gurk, C., Schlager, H., Weingartner, E.: Experimental studies on particle emissions from cruising ship, their characteristic properties, transformation and atmospheric lifetime in the marine boundary layer. Atmos. Chem. Phys. 8, 2387-2403 (2008)

19. Moldanová, J., Fridell, E., Popovicheva, O., Demirdjian, B., Tishkova, V., Faccinetto, A., Focsa, C.: Characterisation of particulate matter and gaseous emissions from a large ship diesel engine. Atmos. Environ. 43, 2632-2641 (2009)

20. Viana, M., Hammingh, P., Colette, A., Querol, X., Degraeuwe, B., Vlieger, I., Aardenne, J.: Impact of maritime transport emissions on coastal air quality in Europe, 2014. Atmos. Environ. 90, 96-105 (2014)

21. Iodice, P., Senatore, A.: Appraisal of pollutant emissions and air quality state in a critical italian region: methods and results. Environ. Progress Sustain. Energy 34, 1497-1505 (2015)

22. Caiazzo, G., Di Nardo, A., Langella, G., Scala, F.: Seawater scrubbing desulfurization: a model for $\mathrm{SO}_{2}$ absorption in fall-down droplets. Environ. Progress Sustain. Energy 31, 277-287 (2012)

23. Kasper, A., Aufdenblatten, S., Forss, A., Mohr, M., Burtscher, H.: Particulate emissions from a low speed marine diesel engine. Aerosol. Sci. Technol. 41, 24-32 (2007)

24. Winnes, H., Fridell, E.: Particle emissions from ships: dependence on fuel type. J. Air Waste Manag. Assoc. 59, 1391-1398 (2009)

25. Wang, M., Zhang, J., Zhang, S., Ma, Q.: Predication emission of a marine two stroke diesel engine based on modeling of radial basis function neural networks. In: Second WRI Global Congress on Intelligent Systems, vol. 3, pp. 184-188. IEEE (2010)

26. Operation on Low Sulphur Fuels, MAN Diesel and Turbo. Augsburg, Germany, Publication no. 5510-0075-01ppr (2014)

27. Preparing for low sulphur operation. Technical update, DNV GL Maritime (2014) https://www.dnvgl.com

28. Abdul-Wahab, S.A.: An application and evaluation of the CAL3QHC model for predicting carbon monoxide concentrations from motor vehicles near a roadway intersection in Muscat, Oman. Environ. Manag. 34, 372-382 (2004)

29. Goldsworthy, L., Goldsworthy, B.: Modelling of ship engine exhaust emissions in ports and extensive coastal waters based on terrestrial AIS data e An Australian case study. Environ. Model. Softw. 63, 45-60 (2015)

30. Petzold, A., Weinzierl, B., Fiebig, M., Lichtenstern, M., Lauer, P., Gurk, C., Franke, K., Weingartner, E.: Particle emissions from ship engines: emission properties and transformation in the marine boundary layer. In: Proceedings of the TAC-Conference, June 26 to 29, 2006, Oxford, UK

31. Tzannatos, E.: Ship emissions and their externalities for the port of Piraeus e Greece. Atmos. Environ. 44, 400-407 (2010)

32. Miola, A., Ciuffo, B.: Estimating air emissions from ships: metaanalysis of modelling approaches and available data sources. Atmos. Environ. 45, 2242-2251 (2011)

33. Schembaria, C., Cavallia, F., Cucciab, E., Hjortha, J., Calzolaic, G., Pérezd, N., Peyd, J., Pratib, P., Raesa, F.: Impact of a European directive on ship emissions on air quality in Mediterranean harbours. Atmos. Environ. 61, 661-669 (2012)

34. US EPA, United States Environmental Protection Agency: User's guide for the ISC3 Dispersion Models. Epa-454/B-95-003b. US EPA OAQPS, Research Triangle Park (1995) 